\title{
Impact of Weight Reduction on Exercise Tolerance and Psychological Wellbeing for Obese Elderly Women
}

\author{
Shehab M Abd El Kader* \\ Department of Physical Therapy for Cardiopulmonary Disorders and Geriatrics, Cairo University, Egypt
}

Submission: January 20, 2017; Published: February 10, 2017

*Corresponding author: Shehab Mahmoud Abd El-Kader, Department of Physical Therapy for Cardiopulmonary Disorders and Geriatrics, Faculty of Physical Therapy, Cairo University, Egypt, Email: profshehab@live.com

\begin{abstract}
Background: Obesity among elderly is an important health-related problem worldwide, to date there is controversy regarding the adverse impact of weight loss among elderly women.

Objective: This study aimed to examine the effects of weight reduction program on exercise tolerance and psychological wellbeing for obese elderly women.

Material and Methods: Sixty obese elderly women enrolled in this study, their age ranged from 60-67 years and their BMI ranged from $31-35 \mathrm{~kg} / \mathrm{m} 2$. All participants were divided into two equal groups: The training group (A) received weight reduction program in the form of moderate intensity aerobic exercise training on treadmill in addition to diet regimen where, the control group (B) received no intervention. Beck Depression Inventory (BDI), Profile of Mood States(POMS), Rosenberg Self-Esteem Scale (RSES), Six Minute Walk Test (6MWT), grip strength and body mass index (BMI) were measured before and after 3 months at the end of the study.
\end{abstract}

Results: There was a significant decrease in BMI, BDI \& POMS and increase in RSES, 6MWT and grip strength in training group (A) at the end of the study with no significant changes in the control group (B). However, no significant differences were found between both groups at the end of the study.

Conclusion: The current study provides evidence that weight reduction program improves exercise tolerance and psychological wellbeing for obese elderly women.

Keywords: Exercise Tolerance; Elderly; Obesity; Psychological Wellbeing; Weight Reduction

\section{Introduction}

Obese elderly women have low physical functioning, energy, and vitality [1]. About two-thirds of the American citizens are overweight and obese [2]. Currently, there is a global concern regarding management of obesity [3]. Overweight and obesity prevalence has increased significantly over the last 30 years, with overweight and obesity now affecting 1.5 billion adults globally [4]. Worldwide, about three million people die every year of obesity-related diseases, including cardiovascular disease, diabetes mellitus and metabolic syndrome [5]. Recently, the prevalence of type 2 diabetes mellitus (T2DM) and cardiovascular disease increased in parallel to prevalence of obesity [6,7]. Obese subjects usually suffer from depression, reduced self-esteem, mobility/functional disability and general health problems [8].
Clinical management of obesity should focus on weight reduction and exercise in an attempt to improve wellbeing [1]. There is evidence that person's exercise capacity Increasing can improved by physical activity [9]. The cornerstones for treatment of obesity are diet and exercise [10]. Proper diet regimen and physical activities are the appropriate behavioral modification to achieve healthy body weight [11]. Obesity is usually associated with depression as $20-50 \%$ of obese subjects suffer from depressions $[12,13]$. The risk of depression increased parallel to the degree of obesity [14]. There is a bi-directional relationship between depression and obesity [15-17], while, others believe that obesity is usually associated with depression development $[18,19]$. The aim of this study was examine the effects of weight reducing program on exercise tolerance and psychological wellbeing for obese elderly women. 


\section{Material and methods}

\section{Subjects}

Sixty elderly obese women enrolled in this study, their age ranged from 60- 67 years and their BMI ranged from $31-35 \mathrm{~kg} /$ $\mathrm{m}^{2}$. Women who were smokers, having respiratory, endocrinal, renal, musculoskeletal, cardiovascular, hepatic disorders, diabetes and chest diseases were excluded. Participants were enrolled in two equal groups: The training group (A) received weight reducing program (moderate intensity treadmill aerobic exercise training and diet regimen) where, the control group (B) received no exercise intervention or diet regimen.

\section{Measurements}

I. Psychological well-being: The Rosenberg SelfEsteem Scale (RSES) was used to measure self-esteem which consisted of 10 items answered on a 4-point Liker scale. The RSES higher scores means greater self-esteem. The Profile of Mood States (POMS) was used to measure mood disturbances, POMS consists of 65 items on a 5-point Liker scale. However, the Beck Depression Inventory (BDI) was used to measure depression, which includes 21 items. The BDI higher scores mean higher depressive symptoms level [20].

II. Hand Grip Strength: Jamar hand dynamometer (Sammons Preston Roland, Cedarburg, WI, USA) was used to measure grip strength of the dominant hand via three successive trials using dynamometer. The degree of elbow flexion was $90^{\circ}$ with no close contact with any body part, two trials were done and the mean value was used in analysis.

III. Six Minute Walk Tests (6MWT): Participants were asked to walk quickly as much as they could for six minutes, two trials were done in two separate days and the mean value was used in analysis [21-23].

IV. Evaluation of anthropometric parameters: Digital stadiometer (JENIX DS 102, Dongsang, South Korea) was used to measure the body height. Balance scale (HC4211, Cas Korea, South Korea) was used to measure body weight and body mass index (BMI) was calculated as BMI = Body weight / (Height $)^{2}$.

\section{Procedures}

Following the previous evaluation, all participants were divided randomly into two equal groups.

A. The training group (A) received weight reduction program includes moderate intensity aerobic exercise training and diet regimen as following:

i. The physical training: The treadmill aerobic exercise training session lasted for 40 minutes (5-minute warmup phase performed on the treadmill (Enraf Nonium, Model display panel Standard, NR 1475.801, Holland) at a low load, training session lasted 30 minutes and finished with 5-minute cooling down), training intensity based on guidelines of the American College of Sport Medicine, using the maximal heart rate index (HR ${ }_{\max }$ ) estimated by: 220age. First 2 weeks $=60-70 \%$ of $\mathrm{HR}_{\text {max }} 3^{\text {rd }}$ to $12^{\text {th }}$ weeks $=$ 70-80\% of $\mathrm{HR}_{\max }$. Three sessions per week for three months [24].

ii. The prescribed low calorie diet: Balanced diet regimen (55\% of energy was from carbohydrates , 15\% of protein and $28-30 \%$ of fat) that provide about 1200 $\mathrm{kcal} /$ day for participants of group (A) to reduce weight as recommended by the World Health Organization.

B. The control group (B): received no training intervention or diet regimen.

\section{Statistical analysis}

The mean values of the investigated parameters obtained before and after three months in both groups were compared using paired " $t$ " test. Independent " $t$ " test was used for the comparison between the two groups $(\mathrm{P}<0.05)$.

\section{Results}

Table 1: Baseline characteristics of study participants.

\begin{tabular}{|c|c|c|c|}
\hline Characteristic & $\begin{array}{c}\text { Training } \\
\text { group (A) }\end{array}$ & $\begin{array}{c}\text { Control group } \\
\text { (B) }\end{array}$ & P value \\
\hline Age (years) & $63.63 \pm 3.12$ & $65.47 \pm 4.82$ & $\mathrm{P}>0.05$ \\
\hline BMI $\left(\mathrm{kg} / \mathrm{m}^{2}\right)$ & $33.42 \pm 4.25$ & $34.31 \pm 3.84$ & $\mathrm{P}>0.05$ \\
\hline SBP $(\mathrm{mmHg})$ & $136.73 \pm 10.82$ & $139.12 \pm 10.26$ & $\mathrm{P}>0.05$ \\
\hline DBP $(\mathrm{mmHg})$ & $87.55 \pm 8.86$ & $88.74 \pm 7.53$ & $\mathrm{P}>0.05$ \\
\hline
\end{tabular}

BMI: Body Mass Index; SBP: Systolic Blood Pressure; DBP: Diastolic Blood Pressure

Table 2: Mean value and significance of measured variables of the training group (A) before and at the end of the study.

\begin{tabular}{|c|c|c|c|c|}
\hline & \multicolumn{2}{|c|}{ Mean +SD } & \multirow{2}{*}{ T-value } & \multirow{2}{*}{ P-value } \\
\hline & Before & After & & \\
\hline BMI $\left(\mathrm{kg} / \mathrm{m}^{2}\right)$ & $\begin{array}{c}33.42 \pm \\
4.25\end{array}$ & $\begin{array}{c}28.13 \pm \\
3.86^{*}\end{array}$ & 7.84 & $\mathrm{P}<0.05$ \\
\hline $\begin{array}{l}\text { Hand grip strength } \\
\text { (mmHg) }\end{array}$ & $\begin{array}{c}140.53 \pm \\
20.16\end{array}$ & $\begin{array}{c}171.14 \pm \\
23.42^{*}\end{array}$ & 8.12 & $\mathrm{P}<0.05$ \\
\hline $\begin{array}{l}\text { Six minute walk test } \\
\text { (meter) }\end{array}$ & $\begin{array}{l}316.17 \pm \\
48.65\end{array}$ & $\begin{array}{l}423.12 \pm \\
51.34^{*}\end{array}$ & 9.36 & $\mathrm{P}<0.05$ \\
\hline Self-esteem (RSES) & $\begin{array}{l}22.36 \pm \\
3.14\end{array}$ & $\begin{array}{c}27.15 \pm \\
3.72^{*}\end{array}$ & 6.17 & $\mathrm{P}<0.05$ \\
\hline Depression (BDI) & $\begin{array}{l}8.11 \pm \\
2.37\end{array}$ & $\begin{array}{l}5.87 \pm \\
1.86^{*}\end{array}$ & 5.46 & $\mathrm{P}<0.05$ \\
\hline $\begin{array}{c}\text { Total mood } \\
\text { disturbance (POMS) }\end{array}$ & $\begin{array}{l}24.27 \pm \\
3.56\end{array}$ & $\begin{array}{c}20.18 \pm \\
3.19 *\end{array}$ & 6.23 & $\mathrm{P}<0.05$ \\
\hline
\end{tabular}

BMI: Body Mass Index; RSES: Rosenberg Self-Esteem Scale; BDI: Beck Depression Inventory; POMS: Profile of Mood States $\left(^{*}\right)$ indicates a significant difference between the two groups; $\mathrm{P}<0.05$. 
(Table 1) shows the baseline participant's characteristics who shared in this study. There was no significant differences in participant's characteristics between both groups. Statistical analysis proved that there was a significant decrease in BMI, BDI \& POMS and increase in RSES, 6MWT and grip strength in the training group (A) at the end of the study (Table 2), however changes in the control group (B) were not significant (Table 3). Moreover, the differences between the investigated parameters mean levels of both groups were significant (Table 4).

Table 3: Mean value and significance of Mean value and significance of measured variables of the control group (B) before and at the end of the study.

\begin{tabular}{|c|c|c|c|c|}
\hline \multirow{2}{*}{} & \multicolumn{2}{|c|}{ Mean +SD } & \multirow{2}{*}{ T-value } & P-value \\
\cline { 2 - 3 } & Before & After & & \\
\hline BMI $\left(\mathrm{kg} / \mathrm{m}^{2}\right)$ & $\begin{array}{c}34.31 \pm \\
3.84\end{array}$ & $\begin{array}{c}34.56 \pm \\
3.98\end{array}$ & 0.79 & $\mathrm{P}>0.05$ \\
\hline $\begin{array}{c}\text { Hand grip strength } \\
\text { (mmHg) }\end{array}$ & $\begin{array}{c}137.18 \pm \\
18.21\end{array}$ & $\begin{array}{c}136.13 \pm \\
17.85\end{array}$ & 1.23 & $\mathrm{P}>0.05$ \\
\hline $\begin{array}{c}\text { Six minute walk } \\
\text { test (meter) }\end{array}$ & $\begin{array}{c}311.37 \pm \\
47.63\end{array}$ & $\begin{array}{c}308.12 \pm \\
45.77\end{array}$ & 1.47 & $\mathrm{P}>0.05$ \\
\hline $\begin{array}{c}\text { Self-esteem (RSES) } \\
18.91 \pm \\
3.55\end{array}$ & $\begin{array}{c}17.18 \pm \\
3.34\end{array}$ & 0.84 & $\mathrm{P}>0.05$ \\
\hline $\begin{array}{c}\text { Depression (BDI) } \\
8.20 \pm 2.46\end{array}$ & $\begin{array}{c}8.31 \pm \\
2.53\end{array}$ & 0.58 & $\mathrm{P}>0.05$ \\
\hline Total mood & $24.35 \pm$ & $24.58 \pm$ & 0.91 & $\mathrm{P}>0.05$ \\
disturbance (POMS) & 3.92 & 4.21 & 0.91 \\
\hline
\end{tabular}

BMI: Body Mass Index; RSES: Rosenberg Self-Esteem Scale; BDI: Beck Depression Inventory; POMS: Profile of Mood States $\left(^{*}\right)$ indicates a significant difference between the two groups; $\mathrm{P}<0.05$.

Table 4: Mean value and significance of Mean value and significance of measured variables of both groups after treatment.

\begin{tabular}{|c|c|c|c|c|}
\hline & Mean +SD & T-value & P-value \\
\hline & $\begin{array}{c}\text { Training } \\
\text { group (A) }\end{array}$ & $\begin{array}{c}\text { Control } \\
\text { group ( B) }\end{array}$ & & \\
\hline BMI (kg/m²) & $\begin{array}{c}28.13 \pm \\
3.86^{*}\end{array}$ & $34.56 \pm 3.98$ & 6.11 & $\mathrm{P}<0.05$ \\
\hline $\begin{array}{c}\text { Hand grip strength } \\
\text { (mmHg) }\end{array}$ & $\begin{array}{c}171.14 \pm \\
23.42^{*}\end{array}$ & $\begin{array}{c}136.13 \pm \\
17.85\end{array}$ & 7.32 & $\mathrm{P}<0.05$ \\
\hline $\begin{array}{c}\text { Six minute walk } \\
\text { test (meter) }\end{array}$ & $\begin{array}{c}423.12 \pm \\
51.34^{*}\end{array}$ & $\begin{array}{c}308.12 \pm \\
45.77\end{array}$ & 8.14 & $\mathrm{P}<0.05$ \\
\hline $\begin{array}{c}\text { Self-esteem (RSES) } \\
27.15 \pm \\
3.72^{*}\end{array}$ & $17.18 \pm 3.34$ & 5.28 & $\mathrm{P}<0.05$ \\
\hline $\begin{array}{c}\text { Depression (BDI) } \\
5.87 \pm 1.86^{*}\end{array}$ & $8.31 \pm 2.53$ & 4.22 & $\mathrm{P}<0.05$ \\
\hline $\begin{array}{c}\text { Total mood } \\
\text { disturbance } \\
\text { (POMS) }\end{array}$ & $\begin{array}{c}20.18 \pm \\
3.19^{*}\end{array}$ & $24.58 \pm 4.21$ & 5.18 & $\mathrm{P}<0.05$ \\
\hline
\end{tabular}

BMI: Body Mass Index; RSES: Rosenberg Self-Esteem Scale; BDI: Beck Depression Inventory; POMS: Profile of Mood States $\left(^{*}\right)$ indicates a significant difference between the two groups; $\mathrm{P}<0.05$.

\section{Discussion}

Compromised psychological wellbeing is one of the common criteria of obese subjects [25] that provide a physical functioning constraints [26], perceived limitations in physical ability [27]. The recommended level of weight loss that approved by the American Diabetes Association wasc7\% body weight through exercise and diet regimen [28] in order to improve well-being and to prevent co-morbidities and to ensure weight maintenance for long time $[29,30]$. This study examined the impact of weight loss on psychological wellbeing and exercise tolerance among elderly obese women.

Results of the present study showed weight loss led to decreased BDI \& POMS and increased RSES, these results are in line with some previous studies in this field [31-35]. proved that one year weight reducing program conducted by 500 obese persons of both gender associated with better psychiatric measure and wellbeing Grave et al. [31]. However, conducted a review on 22 previous and found that long term healthy behavior conducted for 1-5 years resulted in weight loss and better cardiovascular outcomes among patients with type 2 diabetes Lau and Teoh et al. [32]. While, stated that one year weight reducing program consisted of exercise and diet regiemen resulted in better measures of psychological health, anxiety and quality of life among overweight/obese women Imayama et al. [33]. In addition, mentioned that 16-week weight reducing program for 106 obese women and men had type 2 diabetes resulted in moduated emotional distress and better quality of life Wycherley et al. [34]. Moreover, proved that weight reduction improved depressed mode among obese subjects Faulconbridge et al. [35].

The present study revealed that 6MWT and hand grip strength were significantly improved as a result of weight loss among obese elderly women as there is evidence that excess weight may adversely interfere with physical activities [36]. Our findings were consistent with who founded that the distance forecast for 6MWT was higher in the subjects who lost weight Enright and Sherrill [37]. However, proved an improvement of the 6MWT parameters in the late postoperative period of bariatric surgery Maniscalco et al. [38]. In addition, proved that three weeks weight reduction program resulted in increased walking distance as a result of weight loss Lemoine and colleagues [39]. While, found an association between changes in body weight and improved quality of life and physical fitness among obese women as a result of six months lifestyle intervention Ross et al. [40]. Moreover, in their previous on postmenopausal women for one year weight reducing program improved their aerobic fitness Bowen and colleagues [41]. Finally, Look AHEAD trial found that weight management program improves aerobic fitness in overweight subjects with T2DM [42].

\section{Conclusion}

This study provides evidence that weight reduction program improves exercise tolerance and quality of Life for obese elderly women. 


\section{References}

1. Jones G, Sutton A (2008) Quality of life in obese postmenopausal women. Menopause Int 14(1): 26-32.

2. Flegal K, Carroll M, Ogden C, Curtin L (2010) Prevalence and trends in obesity among US adults, 1999-2008. JAMA 303(3): 235-241.

3. Fuller N, Lau N, Denyer G, Simpson A, Gerofi J, et al. (2012) A 12-week, randomized, controlled trial to examine the acceptability of the Korean diet and its effectiveness on weight and metabolic parameters in an Australian overweight and obese population. Obesity Research \& Clinical Practice 6(1): e1-e90.

4. World Health Organisation (2011) Obesity and overweight. Geneva, Switzerland: World Health Organization.

5. World Health Organisation (2011) Global strategy on diet, physical activity and health. Geneva, Switzerland: World Health Organization.

6. Lau D (2011) New insights in the prevention and early management of type 2 diabetes. Can J Diabetes 35(3): 239-241.

7. Sharma A, Lau D (2013) Obesity and Type 2 Diabetes Mellitus. Can J Diabetes 37(2): 63-64.

8. McInnes R, Gray C (2013) Obese Women and Quality of Life. Obesity 15: 585-595.

9. Arterburn D, Crane P, Sullivan S (2004) The coming epidemic of obesity in elderly Americans. J Am Geriatr Soc 52(11): 1907-1912.

10. Skouroliakou M, Giannopoulou I, Kostara C, Koutri K, Stathopoulou $\mathrm{M}$, et al. (2010) Effects of a nutritional intervention in obese postmenopausal women on atypical antipsychotics. Maturitas 67(2): 166-170.

11. American Diabetes Association (2013) Executive Summary: standards of medical care in diabetesd2013. Diabetes Care 36: S4-S10.

12. Simon G, Von Korff M, Saunders K, Miglioretti D, Crane P, et al. (2006) Association between obesity and psychiatric disorders in the US adult population. Arch Gen Psychiatry 63(7): 824-830.

13. Mather A, Cox B, Enn M, Sareen J (2009) Associations of obesity with psychiatric disorders and suicidal behaviors in a nationally representative sample. J Psychosom Res 66(4): 277-285.

14. Petry N, Barry D, Pietrzak R, Wagner J (2008) Overweight and obesity are associated with psychiatric disorders: results from the National Epidemiologic Survey on Alcohol and Related Conditions. Psychosom Med 70(3): 288-297.

15. Pine D, Cohen P, Brook J, Coplan J (1997) Psychiatric symptoms in adolescence as predictors of obesity in early adulthood: a longitudinal study. Am J Public Health 87(8): 1303-1310.

16. Stice E, Presnell K, Shaw H, RohdeP (2005) Psychological and behavioral risk factors for obesity onset in adolescent girls: a prospective study. J Consult Clin Psychol 73(2): 195-202.

17. Murphy J, Horton N, Burke J, Monson R, Laird N, et al. (2009) Obesity and weight gain in relation to depression: findings from the Stirling County Study. Int J Obes 33(3): 335-341.

18. Herva A, Laitinen J, Miettunen J, Veijola J, Karvonen J, et al. (2006) Obesity and depression: results from the longitudinal Northern Finland 1966 Birth Cohort Study. Int J Obes 30(3): 520-527.

19. Roberts R, Deleger S, Strawbridge W, Kaplan G (2003) Prospective association between obesity and depression: evidence from the Alameda County Study. Int J Obes Relat Metab Disord 27(4): 514-521.

20. Palmeira A, Branco T, Martins S, Minderico C, Silva M, etal. (2010) Change in body image and psychological well-being during behavioral obesity treatment: Associations with weight loss and maintenance. Body Image 7(3): 187-193.
21. Turner S, Eastwood P, Cecins M, Hillman D, Jenkins C (2004) Physiologic responses to incremental and self-paced exercise in COPD: A comparison of three tests. Chest 126(3): 766-773.

22. Larsson U, Karlsson J, Sullivan, M (2002) Impact of overweight and obesity on health-related quality of life-Swedish populations study. International Journal of Obesity 26(3): 417-424.

23. Blain H, Jaussent A, Béziat S, Dupuy AM, Bernard PL, et al. (2012)Low serum IL-6 is associated with high 6-minute walking performance in asymptomatic women aged 20 to 70 years. Exp Gerontol 47(2): 143148.

24. Sciacqua A, Candigliota M, Ceravolo R, Scozzafava A, Sinopoli F, et al. (2003) Weight loss in combination with physical activity improves endothelial dysfunction in human obesity. Diabetes Care 26(6): 16731678.

25. Finkelstein MM (2000) Body mass index and quality of life in a survey of primary care patients. J Fam Pract 49(8): 734 -737.

26. Doll HA, Peterson SE, Stewart-Brown SL (2000) Obesity and physical and emotional wellbeing: associations between body mass index, chronic illness, and the physical and mental components of the SF-36 questionnaire. Obes Res 8(2): 160-170.

27. Richards MM, Adams TD, Hunt SC (2000) Functional status and emotional wellbeing, dietary intake, physical activity of severely obese subjects. J Am Diet Assoc 100(1): 67-75.

28. American Diabetes Association (2013) Diagnosis and Classification of Diabetes Mellitus. Diabetes Care 36: S67-S74.

29. Wu T, Gao X, Chen M, van Dam RM (2009) Long-term effectiveness of diet-plus exercise interventions vs. diet-only interventions for weight loss: a meta-analysis. Obes Rev 10(3): 313-323.

30. Deed G (2014) Integrative care of type 2 diabetes mellitus. Advances in Integrative Medicine 1(1): 55-58.

31. Grave R, Calugi S, Petroni M, Di Domizio S, Marchesini G (2010) Weight management, psychological distress and binge eating in obesity. A reappraisal of the problem. Appetite 54(2) : 269-273.

32. Lau DC, Teoh H (2013) Benefits of Modest Weight Loss on the Management of Type 2 Diabetes Mellitus. Can J Diabetes 37(2): 128134.

33. Imayama I, Alfano C, Kong A, Foster-Schubert K, Bain C, etal. (2011) Dietary weight loss and exercise interventions effects on quality of life in overweight/obese postmenopausal women: a randomized controlled trial. International Journal of Behavioral Nutrition and Physical Activity 8: 118-129.

34. Wycherley T, Clifton P, Noakes M, Brinkworth G (2014) Weight loss on a structured hypocaloric diet with or without exercise improves emotional distress and quality of life in overweight and obese patients with type 2 diabetes. Journal of Diabetes Investigation 5(1): 94-98.

35. Faulconbridge L, Wadden T, Rubin R, Walkup A, Fabricatore A, et al. (2012) One-year changes in weight and symptoms of depression in depressed vs. non-depressed individuals in the Look AHEAD study. Obesity 20(4): 783-793

36. Hulens M, Vansant G, Lysens R, Claessens AL, Muls E (2001) Exercise capacity in lean versus obese women. Scand J Med Sci Sports 11(5): 305-309.

37. Enright PL, Sherrill DL (1998) Reference equations for the six-minute walk in healthy adults. Am J Respir Crit Care Med 158: 1384-1387.

38. Maniscalco M, Zedda A, Giardiello C, Faraone S, Cerbone MR, et al. (2006) Effect of bariatric surgery on the six-minute walk test in severe uncomplicated obesity. Obes Surg 16(7): 836-841.

39. Lemoine S, Rossell N, Drapeau V, Poulain M, Garnier S, et al. (2007) 
Effect of weight reduction on quality of life and eating behaviors in obese women. Menopause 14(3 Pt 1): 432-440.

40. Ross KM, Milsom VA, Rickel KA, Debraganza N, Gibbons LM, et al. (2009) The contributions of weight loss and increased physical fitness to improvements in health-related quality of life. Eat Behav 10(2): 8488.

This work is licensed under Creative Commons Attribution 4.0 Licens

DOI: 10.19080/OAJGGM.2017.01.555551
41. Bowen DJ, Fesinmeyer, Yasui Y, Tworoger S, Ulrich CM, et al. (2006) Randomized trial of exercise in sedentary middle aged women: effects on quality of life. Int J Behav Nutr Phys Act 3: 34.

42. Williamson DA, Rejeski J, Lang W, Van Dorsten B, Fabricatore AN, et al. (2009) Impact of a weight management program on health-related quality of life in overweight adults with type 2 diabetes. Arch Intern Med 169(2): 163-171.

\section{Your next submission with Juniper Publishers will reach you the below assets}

- Quality Editorial service

- Swift Peer Review

- Reprints availability

- E-prints Service

- Manuscript Podcast for convenient understanding

- Global attainment for your research

- Manuscript accessibility in different formats ( Pdf, E-pub, Full Text, Audio)

- Unceasing customer service

Track the below URL for one-step submission https://juniperpublishers.com/online-submission.php 